\title{
Wetlands of Darbhanga District: A Basis of Sustainable Livelihood
}

\author{
Shailendra Kumar Roy* \\ Amar Nath Mishra P G College, Dubey Chhapra, Ballia (U.P.), India \\ *Corresponding author
}

\section{A B S T R A C T}

\begin{tabular}{|l|}
\hline Ke y w o r d s \\
Wetland, \\
Biodiversity, \\
Micro-area \\
approach, Empirical \\
assessment, \\
Sustainable \\
livelihood \\
\hline Article Info \\
\hline $\begin{array}{l}\text { Accepted: } \\
\text { 24 September } 2020 \\
\text { Available Online: } \\
\text { 10 October } 2020\end{array}$ \\
\hline
\end{tabular}

\section{Introduction}

Darbhanga district is a flood prone region of North Bihar, geographically identified as an area of tectonic land depressions. The district comprises vast stretches of wetlands locally called as chaur, which are not only highly productive but hold significance from the biodiversity point of view. Kusheshwarasthan is an important wetland site in the district. Apart from these natural wetlands, there are numerous 'Talab' (artificial ponds/tanks) lying dotted all over the district and receiving water from ground water seeps, flooded rivers and monsoon rains. These water bodies are used for fisheries, makhana (Euryale ferox) and singhara (Trapa bispinosa) cultivation, irrigation and provide the basis of livelihood for human beings.

Wetlands are critical resources which are very essential for human society. Its importance arises from interaction of the ecological functions that act with human ecosystem. It plays a vital role in sustaining livelihood. It works through a range of ecosystem services, which bring both physical and non-physical benefits to human being.

Ecosystem services are defined by the Millennium Ecosystem Assessment (MEA, 2005) as "the benefits people obtain from 
ecosystems". Every wetland performs diverse functions and provides different ecosystem services. Water is the fundamental component that supports the functioning and production of all wetland ecosystem services (MEA, 2005).

\section{Materials and Methods}

The researcher himself belongs to the district under investigation and has been observing the nature of wetlands for a long time. Different kinds of flying sample survey were conducted on these wetlands in Darbhanga district and pattern of their utilization in terms of wetland products growing therein. The result of empirical assessment and flying sample survey become the basis of this research paper.

The study was addressed to the study of sustainable livelihood in the area. This was a micro-area approach for the assessment of wetland product-based economy and their role in sustaining livelihood. The main objective of the study was to highlight the value of wetland and their product in sustaining livelihood.

\section{Results and Discussion}

\section{Economic functions: As a livelihood support}

Though most wetland functions like water storage, ground water recharge, water purification, checking erosion and biological production can be evaluated in economic terms; there are many direct economic benefits in the form of harvestable resources for many of which traditional societies have remained dependent upon wetlands for millennia. These values have already been described above. What need to be stressed here is that an assessment of wetland values cannot be made in purely economic terms without taking into consideration the needs and dependence on wetlands of the traditional societies and local communities whose perception of an economic values is generally very different from that of an urban or industrial economist. Besides the foregoing quantifiable and conjunctive values, wetlands also have an important non-consumptive value. It lies in their providing aesthetic setting for cultural and recreational activities such as swimming, fishing, bird-watching, meeting place for shared gossips and friendship or just relaxing and marveling at nature's beauty. Wetlands are a social site that connects to the emotional, cultural and religious sentiments of people living in and around.

Darbhanga district of North Bihar plain is known for its water bodies. The area is famous for its ponds, fish verities and makhana (gorgon nut) (Table 1). Besides the natural water bodies of different size, numerous artificial ponds/tanks are located in the region. These wetlands of the region are a repository of aquatic biodiversity and provide a basis of sustainable livelihood to the traditional societies and local communities. These are-

Blue revolution: The river basins of north Bihar plain especially Darbhanga district are replete with a series of shallow water bodies, locally called chaurs. These chaurs are spread over 29706 ha in Darbhanga district. These biologically sensitive and fragile areas are repository of a variety of fresh water and ornamental fishes. These chaurs provide a basis to the capture fishes with a production rate of $40-50 \mathrm{~kg} / \mathrm{ha} /$ year. Greater colonization of macrophytes and habitat destruction hinders the fisheries. Despite having a vast potential of fish production the state lags behind in meeting the total fish demand. Against an annual requirement of 5.80 lakh metric tonnes the state produces only 4 lakh 
metric tonnes of fish. Similarly, the state produces only 350 metric tonnes fish seeds against the demand of 800 metric tonnes fish seeds. However certain managed pockets have shown high fish production to the tune of over $1000 \mathrm{~kg} / \mathrm{ha} /$ year. The existing gap between demand and supply of fish seed provides enormous opportunities for unemployed youth in the area to invest in fish seed production. Darbhanga district attracted the youth to venture in fish seed business because of a high profit margin. The State Fisheries Policy envisages recognizing this unique property regime for cooperative management wherein cultivation is to be integrated with fisheries (Jha et al., 2014).

Ornamental Fishes: Ornamental fishes are characterized by a wide variety of colour, shape and size pattern that are kept in aquarium to overcome pressure from day to day materialistic life. Due to its various colour pattern and natural beauty, these fishes are called as living jewels. In Bihar, not much attention has been given to ornamental fishes. Several types of ornamental fishes have not been popular yet. North Bihar has many natural resources in the form of wetlands. There are many rivers, chaurs (Land depression), moins (Oxbow lakes), tanks, etc. in which many wild ornamental fishes inhabit.

Darbhanga district is rich in large fresh water resource such as rivers, Chaur, moins, artificial tanks, etc. and is still an untouched sector for exploitation of wild ornamental fishes. Some of important ornamental fishes are given in table 2 .

\section{Makhana cultivation}

Euryale ferox Salisb, commonly known as Makhana, is an important aquatic plant and has immense potential to support the livelihood to thousands of poor farmers, particularly fisherman community in North Bihar region, where agriculture is complex, diverse and risk prone. It is also known as Gorgon nut or Fox nut and grown in stagnant perennial water bodies like ponds, Chaurs, Moins etc. Makhana seeds are known as Black Diamond. Its plant grows in tropical and sub-tropical climatic condition. Makhana requires $20^{\circ} \mathrm{C}-35^{\circ} \mathrm{C}$ temperature, $50 \%-90 \%$ relative humidity and $100 \mathrm{~cm}-250 \mathrm{~cm}$ of annual rainfall for its proper growth and development (Mandal et al.,2010).

India is the only country on the global level where commercial cultivation of Makhana is done. Within India, Bihar is the leading state in the production of Makhana till date. In North Bihar, there are numerous natural and artificial ponds and tanks, chaurs and low lying waterlogged areas. Hence, North Bihar is known as the natural abode of Makhana production.

In North Bihar, commercially, major Makhana producing districts are Darbhanga, Madhubani, Samastipur, Saharsa, Supaul, Araria, Kishanganj, Purnia and Katihar. Approximately, $80 \%$ of total production of processed Makhana comes from Darbhanga, Madhubani, Purnia and Katihar district alone.

Area under makhana cultivation is about 13,000 ha. Keeping in view of its commercial importance, a regional research centre was setup to conduct research on various aspects of Makhana in Darbhanga district under the administrative control of ICAR (Indian Council of Agricultural Research) Research Complex for Eastern Region (Kumar et al., 2011) (Table $3)$. 
Table.1 Important fishes found in wetlands of Darbhanga district

\begin{tabular}{|c|c|c|}
\hline S. No. & Local name & Zoological name \\
\hline 1. & Bulla & Glossogobius giuris \\
\hline 2. & Kanti & M. Seenghala \\
\hline 3. & Mangur & Calaria sbatrachus Linn. \\
\hline 4. & Gainchi & Mastucombelus pancalus \\
\hline 5. & Tengra & Mystus tengla \\
\hline 6. & Kabai & Anabas testudineu \\
\hline 7. & Singhi & Heteropneustes fossilis \\
\hline 8. & Garai & Channa punctatus \\
\hline 9. & Jhinga & Macrobrachium lammeri \\
\hline 10. & Katri & Catla catla \\
\hline 11. & Naini & Cirrhinus mrigala \\
\hline 12. & Rehu & Labeo rohita \\
\hline 13. & Marwa & Oxygaster culpeoides \\
\hline 14. & Saur & Channa matulius \\
\hline
\end{tabular}

Source: Roy, 2019

Table.2 Important ornamental fishes found in wetlands of Darbhanga district

\begin{tabular}{|l|l|l|}
\hline S. No. & Local name & Scientific Name \\
\hline 1. & Kotri & Colisa spp \\
\hline 2. & Khosti & Colis alalia \\
\hline 3. & Sand loach & Lepido cephalus \\
\hline 4. & Nekti loach & Botia derio \\
\hline 5. & Tiger loach & Botia almorhae \\
\hline 6. & Galpuulani & Eresthistes triangularis \\
\hline 7. & Bulla & Glossogobius giuris \\
\hline 8. & Banspatta & Alia coila \\
\hline 9. & Flying barb & Esomus danivica \\
\hline 10. & Chanari & Chanda nama \\
\hline 11. & Indian glass fish & Chanda ranga \\
\hline 12. & Kawua & Xenantodon cancila \\
\hline 13. & gaichi & Mastacembelus oatesii \\
\hline 14. & Katgaichi & Mastecembelus sp. \\
\hline
\end{tabular}

Source: Das et. al. (2015) 
Table.3 Comparison of makhana cultivation in pond ecosystem and in agricultural fields

\begin{tabular}{|c|c|c|c|}
\hline S. No. & Parameters & Pond ecosystem & Agricultural field \\
\hline 1. & Water requirement & $4-6$ feet & 1 feet \\
\hline 2. & Seed requirement & $80-90 \mathrm{~kg} / \mathrm{ha}$ & $20 \mathrm{~kg} / \mathrm{ha}$ \\
\hline 3. & Source of water & Perennial water bodies & Irrigation or rain water \\
\hline 4. & $\begin{array}{l}\text { Fertilizers and } \\
\text { manure }\end{array}$ & $\begin{array}{l}\text { Not possible due to high } \\
\text { depth of standing water }\end{array}$ & Can be applied very easily \\
\hline 5. & Crop duration & 8-10 months & 4-5 months \\
\hline 6. & Seed yield & $1.8-2.0$ ton/ha & 2.6-3.0 ton/ha \\
\hline 7. & $\begin{array}{l}\text { Intensification } \\
\text { cropping system }\end{array}$ & Makhana + water chestnut & $\begin{array}{l}\text { Makhana + water chestnut } \\
\text { Makhana + Barseem } \\
\text { Makhana + Rice+wheat }\end{array}$ \\
\hline 8. & Net income & Low to medium & High to Very high \\
\hline 9. & Capital investment & High to very high & Medium to low \\
\hline 10. & $\begin{array}{l}\text { Scope of horizontal } \\
\text { expansion }\end{array}$ & Limited & Wide \\
\hline
\end{tabular}

Source: Kumar et al., 2011

Table.4 Aquatic plants as a basis of livelihood around wetlands of Darbhanga district

\begin{tabular}{|c|c|c|c|c|}
\hline S. No. & Local Name & Botanical Name & $\begin{array}{l}\text { Natural/ } \\
\text { Habitat }\end{array}$ & Livelihood Purposes \\
\hline 1. & Tal Makhana & Astercantha longifolia Nees & Wild & Leafy green, Source of drug \\
\hline 2. & Makhana & Euryale forex Salisb & Cultivated & $\begin{array}{l}\text { Subsidiary food, Component } \\
\text { of integrated aquacultural, } \\
\text { pops a ritual items }\end{array}$ \\
\hline 3. & Singhara & Trapa bispinosaRoxb. & Cultivated & Subsidiary food \\
\hline 4. & Purain(Kamal) & Nelumbo nисifera Gaertn. & Wild & $\begin{array}{l}\text { Subsidiary food, flower and } \\
\text { seeds as ritual item }\end{array}$ \\
\hline 5. & Bhent & Nymphaea alba Linn. & Wild & Subsidiary food \\
\hline 6. & Jalkumbhi & Eichhornia crassipes Solms. & Wild & $\begin{array}{l}\text { Energy fuel, Fishing shelter } \\
\text { belt, Fodder, }\end{array}$ \\
\hline 7. & Motha & Cyperus rotundusLinn. & Wild & $\begin{array}{l}\text { Culms used for making } \\
\text { Shitalpaati }\end{array}$ \\
\hline 8. & Sarahanchi & Alternanthera & Wild & Fodder, Fish shelter Belt \\
\hline 9. & Manager & Sesbania rostrata Bremek. & $\begin{array}{l}\text { Wild and } \\
\text { Cultivated }\end{array}$ & \\
\hline 10. & Kataraghas & VetiveriazizanionidesLinn. & Wild & $\begin{array}{l}\text { Flood fighter, Sikki } \\
\text { handicraft }\end{array}$ \\
\hline 11. & Khubahi & Scirpus articulatus Linn. & Wild & Subsidiary food \\
\hline 12 & Korhila & Aeschynomene indica & wild & Carve items, floating boat \\
\hline
\end{tabular}

Source: Jha (2012) 
Fig.1 Influence of wetland ecosystems on human

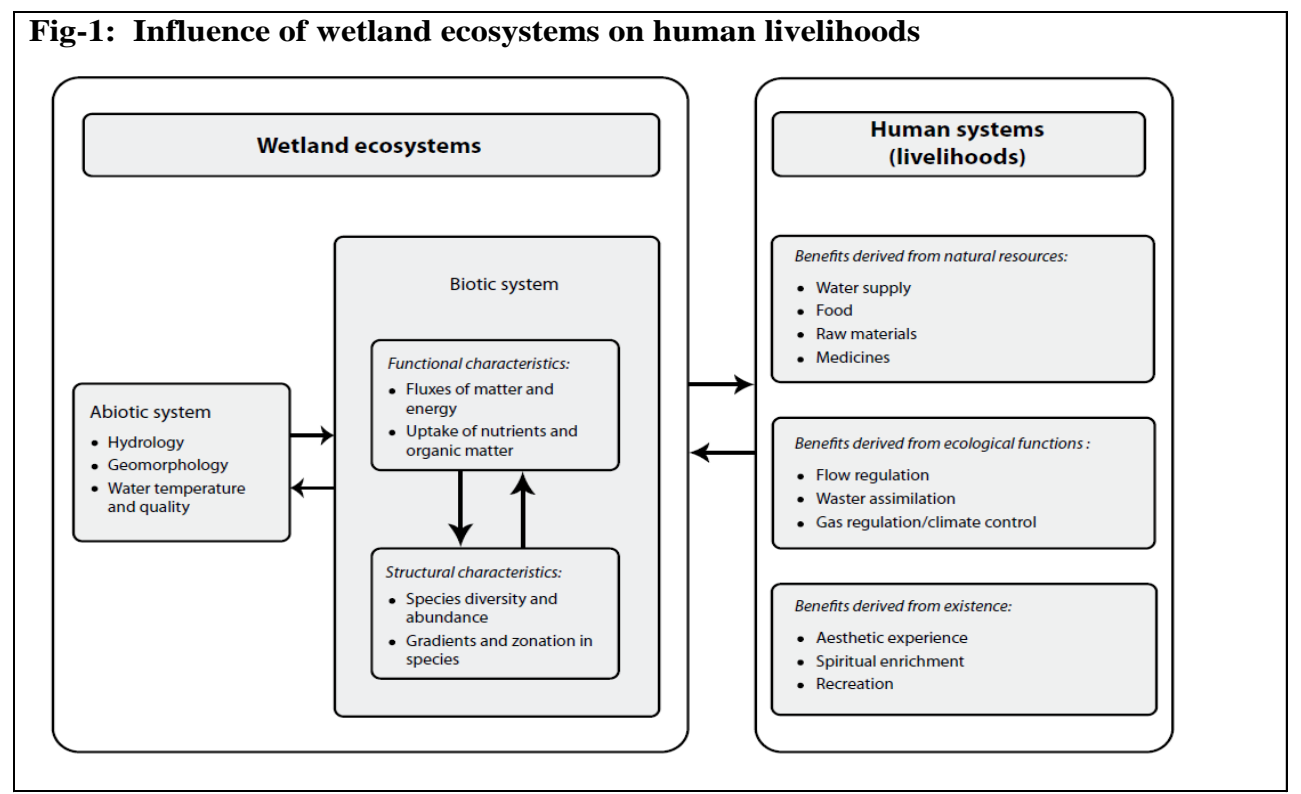

Source: Lorenz et al., (1997)

Fig.2 Different stages of makhana cultivation

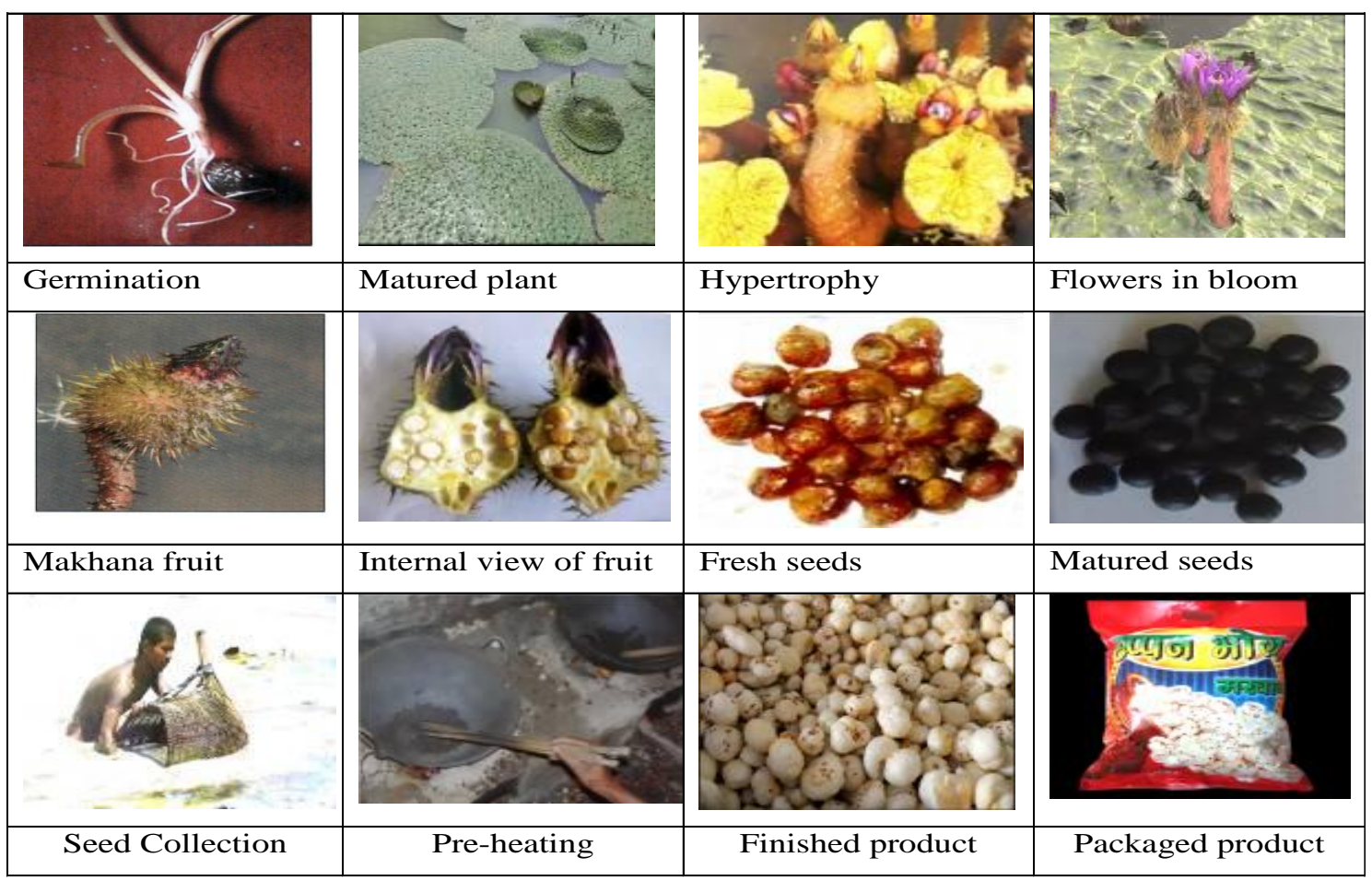

Source- Compiled by author 
Fig.3 Different wetland products and their uses

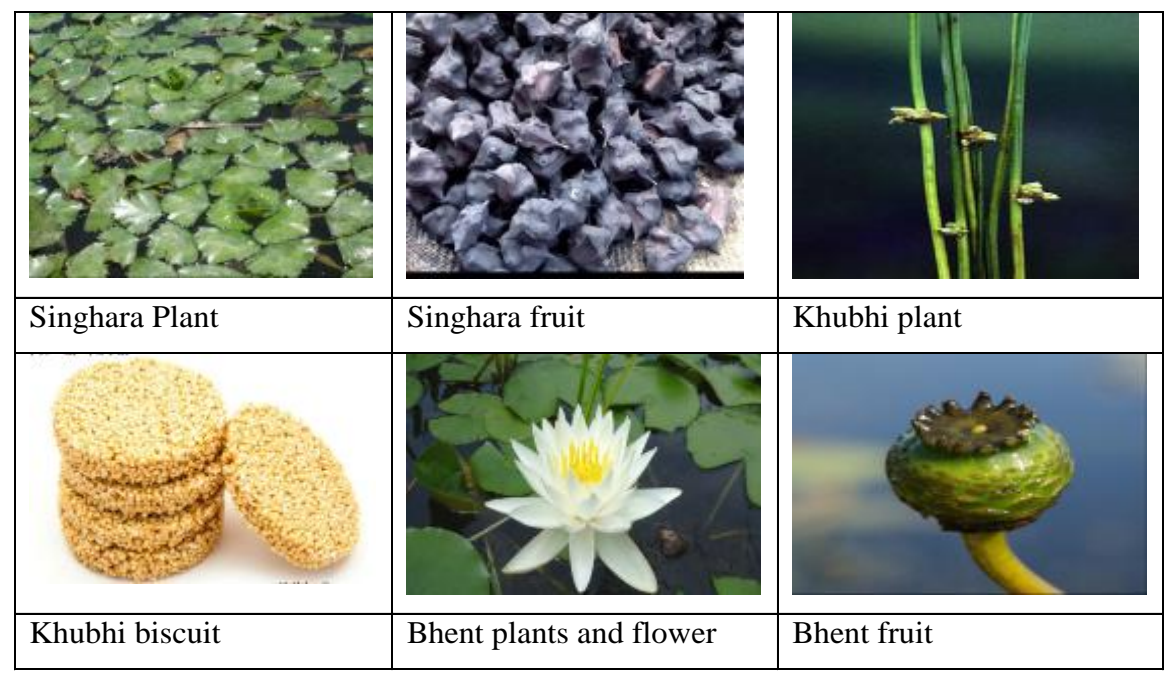

Source- Compiled by author

In general, Makhana is a crop of pond ecosystem. A field based cultivation techniques has been developed in order to enhance the productivity and facilitate the horizontal expansion of Makhana, which is being adopted by the farmers of the region. Makhana based cropping system, i.e. Makhana-Water chestnut, MakhanaBarseem, and Makhana-Rice-Wheat has been developed. Makhana with fish and Waterchestnut integrated farming system model have been developed which is gaining popularity among the farmers. Economics of different Makhana based cropping systems have been worked out and net monetary returns have been recorded highest through makhana- Rice-Wheat cropping system (Rs 1,22570/ha), followed by Makhana- Barseem (Rs 98,465/ha) and Makhana- Water chestnut(Rs 88,790/ha). Net monetary returns through Makhana-Fish-Water chestnut was estimated Rs 88,910/ha. (Kumar et. al., 2011).

\section{Other Wetland Products}

A survey was done in the study area to know the diversity and utilization of aquatic plants used by the people for their livelihood. About a dozen aquatic plants have been found to be intimately associated with livelihood practices in this region of North Bihar plain. Of these, Makhana (Eurale ferox) and Singhara(Trapa bispinosa) are cultivated as commercial crops and constitute subsidiary food items. Other aquatic plants like Khubani (Scirpus articulatus) and Bhent (Nymphaea alba) are collected from the wild. A number of aquatic plants like Sarhanchi, Tal Makhana etc. are also collected from the wild to be used as leafy greens (Jha et al, 1996).

Singhara (Trapa bispinosa): This aquatic plant aregrowing in shallow and slow moving water. Plant bear ornately shaped fruits. The fruit contains a single large starchy seed. These edible seeds are cultivated for subsidiary food. It has much wider distribution as against Makhana whose cultivation is localized around Milkichak wetland. Waterlogged areas alongside of Darbhanga-Lateriasarai rail line are settled to the growers for its cultivation.

Khubahi (Scirpus articulatus): It is a densely tufted plant growing in open wet places in 
settled lowland areas. Khubani are eaten as granular sweets in India. As dietary plant khubanihas been investigated by Gupta and Saha (1977) for its chemical composition and nutritive values. Its seeds are collected and processed by the people after the rainy season is over to obtain its lightest pops which are available as granular sweets and sold under the name of 'KhubahiRamdana' in the area. (Jha et al, 2002).

Bhent (Nymphaea alba): This is an aquatic flowering plant. It grows in large lakes and ponds that is $30-150 \mathrm{~cm}$ deep. Its seeds are collected, processed and eaten by the people as subsidiary food.

Korhila (Aeschynomene indica):This is one of the known lightest woods. It provides a basis of livelihood to the gardening community around the wetland area who carve items like Jhaang, Maurs, etc. from it. Fisherman utilize it as floating boat for moving on the water for throwing their fishing nets(Jha and Jha, 2002).

\section{Cultural value of wetlands}

The relationship of people of Darbhanga district with these wetlands has strong reflection in the culture and belief systems. In Mithila region, 'ponds' are treated as daughter. The people had linked their festivals and rituals with the ponds. If there was a marriage or child birth, they would go to the pond and perform their rituals. With onset of Monsoon, the ponds and river channels were cleaned to provide for much needed flood storage. This practice is known as 'joorsital'. The Sankranti of Baishakh month was a sacred duty of every person to clean all the water sources. The active preparation before flood has a Celebrating name 'jhajhar'. Some cultural acts which are associated with wetland of the region are Marriage rituals; Shradh and Tarpan; Emersion of goddess
Saraswati, Durga, Kali, etc.; Bathing on Purnimas, Shankranti and Sun and Moon eclipses; Abode of Goddess Kamla (Goddess of water); Sama-Chakewa; Chat Brata etc. (Table 4).

In conclusion the wetlands are essential for human health and prosperity. They provide us fresh water, maintain ground water, ensure our food security, sustain biodiversity, protect against flooding etc. This is a major source of employment globally and also ideally placed to showcase truly sustainable livelihood. Wetlands of Darbhanga District such as chaur, moin, tal, tank, rivers etc. provide a basis to capture fishes, shell fishes, crabs etc. it supports thousands of people in securing their food supply and sustaining their livelihood. These wetlands are also a habitat for many aquatic plants and animals. Harvesting and processing of these aquatic plants and their fruits, reeds and grasses also provide a basis of livelihood around the wetlands of Darbhanga district.

Kusheshwarasthan wetland of Darbhanga district in North Bihar is known for wintering ground for migratory birds and is also known for Shiva temple. Therefore, it has the potential of being developed as a place for eco-cum-religious tourism. It could create employment opportunities and hence support local people for their livelihood. Darbhanga district is land of rivers and flood plains. These rivers have potential to play a vital role in transporting goods and services in many parts of the region and support livelihood systems of many communities.

\section{References}

Das, J.P.L., Kolay, S.R. and Rahamtullah, M., 2015. Status of ornamental fish diversity in Jhang-A wetland of Kusheshwarsthanchaur. International Journal of Fisheries and Aquatic 
Studies. 2(4):142-146.

Gupta, B.N. and Saha, R.C., 1977. Chemical composition and nutritive value of Jhanji (Scirpus articulatus) a semi aquatic plant. Indian journal of Dairy Science. 30(2): 119-122.

Jha, V., Handoo, J.K. and Ahmad, S.H., 2002.Khobhi in the flood plains of Bihar. Indian Farming. 54:29.

Jha, V. and Jha, A.K., 2002. Ethnic uses of korhila (Aeschynomene sp.) in Mithila (North Bihar, India). In: Rao(Ed.), Advances in Legume Research in India. B.S.M.P.S., Dehradun, pp. 323-331.

Jha, V., Verma, A.B., Jha, P., Jha, M. and Kumar, R., 2014. Wetlands in North Bihar provide a basis to its sustainable development. Journal of Aquatic Biology and Fisheries. 2: 843-851.

Kumar L., Gupta V.K., Jha B.K., Singh I.S., Bhatt B.P. and Singh A.K., 2011. Status of Makhana (Euryale feroxSalisb) Cultivation in India. ICAR Research Complex for Eastern Region, Patna,
Bihar.

Lorenz, C., VanDijk, G.M., Van Huttum, A.G.M. and Cofino, W.P., 1997. Concept in river ecology: implications for indicator development. Regulated rivers: research and management. 13:501-506.

Mandal, R.N., Saha, G.S. and Sarangi, N., 2010. Harvest and processing of Makhana (Euryale feroxSalisb.)-a unique assemblage of traditional knowledge. Indian journal of Traditional knowledge. 9(4):684-688.

Millennium Ecosystem Assessment, 2005. Ecosystems and human wellbeing: wetlands and water. Synthesis. Washington, DC: World Resources Institute.

Roy, S.K. (2019) Dynamics of wetlands: An assessment of ecology, economy and livelihood in Darbhanga district of north Bihar plain. Ph.D. Thesis, Patna University, Patna, India.

\section{How to cite this article:}

Shailendra Kumar Roy. 2020. Wetlands of Darbhanga District: A Basis of Sustainable Livelihood. Int.J.Curr.Microbiol.App.Sci. 9(10): 3097-3105. doi: https://doi.org/10.20546/ijcmas.2020.910.372 